It would be interesting to know the value, if any, of hæmoglobin to copepods, and whether there is a functional reason for its presence in some copepod parasites of fish and absence in others. Experimental work may solve the problem, but meanwhile it is not justifiable to assume ${ }^{2}$ that in Lerncescera oxygen for respiration reaches the parasite through its mouth with the host's hæmoglobin, and that direct gas exchange between copepod and sea water is reduced to a minimum because the cuticle is relatively thick. Such a source of oxygen from the host is improbable, particularly when, as pointed out by the authors quoted, the parasite's meals are taken at rare intervals.

Bedford College,

University of London. July 19.

i Fox, H. M., Nature, 156, 18 (1945).

${ }^{2}$ Sproston, N. G., and Hartley, P. H. T., J. Mar: Biol. Assoc., 25, 393 (1941).

${ }^{3}$ Van Beneden, E., Zool. Anz., 3, 35, 55 (1880).

\section{Edema in Hamsters Infected with Leishmania}

IN the course of work upon the chemotherapy of experimental kala azar, I have observed that Syrian hamsters (Cricetus auratus) with long-standing infections of an Indian strain of Leishmania donovani sometimes develop severe œedema. Ascites and distension of the mesentery with fluid are the first signs of the condition. Later, gross cedema of the subcutaneous tissue develops and the skin is pulled down into a skirt around the flanks by the weight of the fluid it contains. The animal increases rapidly in weight through water retention and dies in a few days. An adult hamster weighing 80-100 gm. may gain $50 \mathrm{gm}$. in weight in the course of a week.

When this observation was first made in 1942, private correspondence with the late Dr. G. W. Dunkin of the Agricultural Research Council, who supplied the hamsters, confirmed the fact that the condition had not been recognized in stock animals.

The condition appears only after several months of infection with leishmania, and not every animal is affected. It does not depend upon the degree of infection as measured by parasite counts in spleen smears ${ }^{1}$. Edematous animals are not suitable for use in tests for leishmanicidal substances, and the difficulty has been overcome by the use of recently isolated Mediterranean strains of leishmania, which produce heavy spleen infections in the course of a few weeks ${ }^{2}$. However, if animals infected with these strains are kept untreated for several months, some of them develop odema. This shows that the condition is not associated with a single strain of leishmania.

Edematous animals exhibit proteinuria; the kidneys are pale and enlarged, and histological examination shows degeneration of the glomeruli and obstruction of the tubules with protein casts. The serum protein in a fow animals was determined by Walther's method ${ }^{3}$; the results for five œdematous animals were: $3 \cdot 8,5 \cdot 4,4 \cdot 6,3 \cdot 5,4 \cdot 9$ per cent of protein respectively, and for two normal animals of the same age, $7 \cdot 1$ and $7 \cdot 6$ per cent. It is evident that severe loss of protein through the kidney is the chief cause of the odema.

All attempts to cultivate a secondary infective agent upon nutrient media or by inoculation of normal animals have so far failed. Intraperitoneal and intracerebral inoculations into mice and hamsters, and inoculation of chick tissue-cultures with a candled suspension of kidney, liver or spleen material from odematous hamsters have also been without result. It seems probable that the nephritis is caused by a toxin liberated by the leishmania parasite under conditions of chronic infection.

The condition of the hamsters recalls that observed in mice infected with Trypanosoma cruzi, which has been investigated by Collier, Fulton and Innes ${ }^{4}$. The underlying cause of the œdema is not, however, the same, because these workers found the kidneys of œdematous mice to be normal.

The Wellcome Laboratories of

Tropical Medicine,

183 Euston Road,

London, N.W.1.

${ }^{1}$ Goodwin, L. G., Trans. Roy. Soc. Trop. Med. and Hyg., 38, 151 (1944). ${ }^{2}$ Goodwin, L. G., Trans. Roy. Soc. Trop. Med. and Hyg., in the press. ${ }^{3}$ Walther, W. W., Lancet, ii, 337 (1941).

4 Collier, H. O. J., Fulton, J. D., and Innes, J. R. M., Ann. Trop. Med. Parasitol., 36, 137 (1942).

\section{Production of $p$-Aminobenzoic Acid by the Tubercle Bacillus}

MANY workers have elaimed that the common sulphanilamides in high concentrations may modify the course of experimental tuberculosis in animals. Much better results have been obtained, however, with the diaminodiphenyl-sulphone and some of its derivativos, for example, promin and diasone. The same applies to promizole, an analogous compound, which is a diaminophenyl-thiazole-sulphone. These sulphones have also shown a certain effect in a prolonged clinical trial, although it is necessary to seek for more effective, or at least less toxic, compounds.

The diaminodiphenyl-sulphone and similar compounds are said to act on sensitive bacteria in the same manner as the sulphanilamides. The fundamental condition for the effectiveness of these compounds against the tubercle bacillus would therefore appear to be that this bacterium also requires $p$-aminobenzoic acid as an essential metabolite. Indirect proof of this is furnished. by the observation that the bacteriostatic action in vitro of sulphathiazole ${ }^{1}$ and promin $^{2}$ on the tubercle bacillus is inhibited by $p$-aminobenzoic acid. We have, however, performed direct analyses ${ }^{3}$, and succeeded in showing that both the tubercle bacillus and the culture medium in which it has been grown contain $p$-aminobenzoic acid. Assuming that $p$-aminobenzoic acid is of functional significance to the bacterium which forms it-and this is highly probable-the experiments with sulphones and related substances in experimental tuberculosis can therefore be considered as well founded.

The determinations were performed in the following manner. A number of flasks, each containing $200 \mathrm{ml}$. of Sauton's synthetic substrate, were inoculated with a virulent human strain (a platinum loop containing on the average $0.1 \mathrm{gm}$. of wet bacilli). The cultures were incubated at $37^{\circ} \mathrm{C}$. for different times. The resultant cakes of bacteria were finely dispersed and washed and dried by suction. The filtrate was sterilized by heat (passage through a Seitz filter did not alter the values) and continuously extracted with ether at $p \mathrm{H} 3 \cdot 8$ for 30 hours. $p$-Aminobenzoic acid was determined colorimetrically in the ether solution 